\section{Detection of Arcobacter spp. in Mytilus galloprovincialis samples collected from Apulia region}

\author{
Elisabetta Bonerba, ${ }^{1}$ Anna Mottola, ${ }^{1}$ \\ Antonio Parisi, ${ }^{2}$ Angela Di Pinto, \\ Andrea Serraino, ${ }^{3}$ Giancarlo Bozzo, ${ }^{1}$ \\ Federica Giacometti, ${ }^{3}$ Edmondo Ceci, ${ }^{1}$ \\ Giuseppina Tantillo' \\ 'Dipartimento di Medicina Veterinaria, \\ Università di Bari, Valenzano (BA); \\ ${ }^{2}$ Istituto Zooprofilattico Sperimentale \\ della Puglia e Basilicata, Putignano (BA); \\ ${ }^{3}$ Dipartimento di Scienze Mediche \\ Veterinarie, Alma Mater Studiorum - \\ Università di Bologna, Ozzano Emilia \\ (BO), Italy
}

\section{Abstract}

The aim of the study was to evaluate the occurrence of Arcobacter spp. in 20 samples of Mytilus galloprovincialis purchased at fish markets in Apulia region. The detection of Arcobacter spp. was performed, after selective enrichment, on modified charcoal cefoperazone deoxycholate (mCCD) agar supplemented with Cefoperazone, Amphotericin B and Teicoplanin (CAT). In 6 out of the 20 tested samples the presence of Arcobacter spp. was found and confirmed by genus-based polymerase chain reaction. All the isolates were identified as belonging to the species Arcobacter butzleri using 16S rDNA sequencing and BLAST online. The results represent the first report in Italy of $A$. butzleri detection in marketed Mytilus galloprovincialis. The survey underlines the epidemiological importance of $A$. butzleri as an emerging pathogen, and highlights that mussels should be considered as a potential cause of foodborne disease outbreak.

\section{Introduction}

Arcobacter spp. was proposed as a new genus in 1991 by Vandamme and De Ley who defined it as aerotolerant campylobacter. This genus belongs to the class Epsilonproteobacteria and to family Campylobacteraceae (Phillips, 2001; Levican et al., 2014). Arcobacter are rod, gram negative, microaerophilic, non-spore forming, motile, curved and occasionally straight organisms which can grow between 15 and $39^{\circ} \mathrm{C}$ (González and Ferrús, 2011; Tabatabaei et al.,
2014). Currently, the genus includes 18 characterized species (Levican et al., 2014; NievaEchevarria et al., 2013), among them, Arcobacter butzleri, Arcobacter cryaerophilus, and Arcobacter skirrowii are considered as potential emerging food borne enteropathogens (Levican and Figueras, 2013) and have been associated with human and animal disease (Tabatabei et al., 2014; Levican et al., 2014; Suelam, 2012). A. butzleri has been classified as a serious hazard to human health by the International Commission on Microbiological Specifications for Foods (ICMFS, 2002) and as a significant zoonotic pathogen (Cardoen et al., 2009). Moreover, $A$. butzleri has been recognised as a cause of traveller's diarrhea (Jiang et al., 2010).

Potential routes of Arcobacter spp. infection in human may be associated to the consumption and/or manipulation of contaminated raw or poorly cooked food of animal origin (Collado and Figueras, 2011; Gonzales and Ferrús, 2011; Hausdorf et al., 2011; Nieva-Echevarria et al., 2013). Furthermore, these bacteria are members of seawater microbiota, wastewater and drinking water reservoirs (Collado et al., 2008). Studies carried out by Fera et al. (2004) suggest that $A$. butzleri arrives in seawater through polluted freshwater and that this organism survives in the marine environment by adhering to zooplankton.

Bivalve mollusks, due to their ability to concentrate microorganisms from contaminated water during their filter-feeding activities, are considered as an important health risk, because they are often eaten poorly cooked and/or raw (Collado et al., 2009; Levican et al., 2014; Ottaviani et al., 2013). Despite this important risk, worldwide only a few surveys investigated the presence of Arcobacter spp. in these products. In Italy, the occurrence of Arcobacter spp. in marketed shellfish has not been investigated yet; only Maugeri and colleagues (2000) detected $A$. butzleri and $A$. nitrofigilis in water and mussels collected from two brackish lakes near Messina, but the isolates were characterized only phenotypically.

The purpose of this study was to evaluate the presence of Arcobacter spp. in Mytilus galloprovincialis sampled at retail in Apulia region (Italy).

\section{Materials and Methods}

\section{Sampling and sample processing}

A total of 20 Mytilus galloprovincialis samples of average size ( $5 \pm 7 \mathrm{~cm}$ length) were collected between January and April 2014 from local fish markets of Apulia region, Italy. Each sample was individually packaged and kept in coolers. Mussels were aseptically prepared for analysis in accordance with the UNI EN ISO
Correspondence: Anna Mottola, Dipartimento di Medicina Veterinaria, Università di Bari, Strada provinciale per Casamassima km. 3, 70010 Valenzano (BA), Italy.

Tel. +39.080 .5443853 - Fax: +39.080 .5443853 .

E-mail: annamottola_2006@libero.it

Key words: Arcobacter butzleri, Mytilus galloprovincialis, Foodborne pathogen.

Conflict of interests: the authors declare no potential conflict of interests

Received for publication: 17 July 2014. Accepted for publication: 14 October 2014.

This work is licensed under a Creative Commons Attribution 3.0 License (by-nc 3.0).

(C) Copyright E. Bonerba et al., 2015 Licensee PAGEPress, Italy

Italian Journal of Food Safety 2015; 4:4583 doi:10.4081/ijfs.2015.4583

6887-3 standard procedure (ISO, 2003). For each sample, $10 \mathrm{~g}$ of meat and intervalvar liquid were homogenized with $90 \mathrm{~mL}$ (1:10, wt/vol) of Arcobacter enrichment broth supplemented with Cefoperazone, Amphotericin B and Teicoplanin (CAT) (selective supplement SR0174E; 0xoid, Basingstoke, UK) in stomacher bags. The bags were closed and incubated at $30^{\circ} \mathrm{C}$ under aerobic conditions for $48 \mathrm{~h}$, and then $200 \mu \mathrm{L}$ of the broth was inoculated by passive filtration onto modified Charcoal Cefoperazone Deoxycholate Agar (mCCDA) supplemented with CAT selective supplement, following the procedure described by Collado et al. (2009). Subsequently, presumptive Arcobacter colonies (small colourless or beige to off-white, translucent, convex with an entire edge, Gram negative) were selected from each plate and transferred to blood agar at least three times to obtain pure cultures. Purified isolates were further subjected to biochemical analysis (catalase, oxidase and urease tests), microscopic examination, and genus-specific polymerase chain reaction (PCR).

\section{DNA extraction and purification}

DNA was extracted by using DNeasy Blood \& Tissue Kit (Qiagen, Valencia, CA, USA). Briefly, bacterial pellet was added to $50 \mu \mathrm{L}$ ATL lysis buffer and $5.56 \mu \mathrm{L}$ of Proteinase $\mathrm{K}(20 \mathrm{mg} / \mathrm{mL})$ and incubated at $56^{\circ} \mathrm{C}$ for $2 \mathrm{~h}$. After adding 55.6 $\mu \mathrm{L}$ AL buffer and 55.6 $\mu \mathrm{L}$ ethanol, the resulting mixture was applied to the DNeasy Mini spin column. The DNA, adsorbed onto the QIAamp silica-gel membrane during subsequent centrifugation steps at $6000 \mathrm{~g}$ for $1 \mathrm{~min}$, was washed using $140 \mu \mathrm{L}$ AW1 and $140 \mu \mathrm{L}$ AW2 washing buffers. Finally, the DNA was eluted with $50 \mu \mathrm{L}$ AE Elution Buffer (Qiagen). The type strains of A. butzleri (ATCC 49616) was used as 
positive control. A negative extraction control (no added tissue) was included to verify the purity of the extraction reagents. The DNA concentration and purity were established by evaluating the ratio $\mathrm{A} 260 \mathrm{~nm} / \mathrm{A} 280 \mathrm{~nm}$ using a Beckman DU-640B spectrophotometer.

\section{Oligonucleotide primers}

The oligonucleotide primers ARCOI (5'-AGA GAT TAG CCT GTA TTG TAT C-3') and ARCOII (5'-TAG CAT CCC CGT TTC GAA TGA-3') reported by Harmon and Wesley (1996) and synthesized by Primm Srl (Milan, Italy) were used.

\section{Polymerase chain reaction assay}

The PCR reactions were performed in a final volume of $25 \mu \mathrm{L}$, using $12.5 \mu \mathrm{L}$ of HotStarTaq Master Mix 2X (Qiagen), containing 2.5 units of HotStarTaq DNA polymerase, $1.5 \mathrm{mM}$ of $\mathrm{MgCl}_{2}$ and $200 \mu \mathrm{L}$ of each dNTP. Then, $1 \mu \mathrm{M}$ of each oligonucleotide primer and $1 \mu \mathrm{L}$ of DNA were added. The amplification profile involved an initial denaturation step at $95^{\circ} \mathrm{C}$ for $5 \mathrm{~min}$, followed by 30 amplification cycles. Each amplification cycle consisted of $30 \mathrm{~s}$ at $94^{\circ} \mathrm{C}$, $30 \mathrm{~s}$ at $51^{\circ} \mathrm{C}$ and $60 \mathrm{~s}$ at $72^{\circ} \mathrm{C}$. A primer extension step $\left(72^{\circ} \mathrm{C}\right.$ for $\left.10 \mathrm{~min}\right)$ followed the final amplification cycle. The positive and negative controls for the extraction were included. The PCR reactions were processed in a Mastercycler Personal (Eppendorf, Hamburg, Germany). All reactions were performed in duplicate.

\section{Detection of amplified products}

Polymerase chain reaction amplified products were analyzed by electrophoresis on $1.5 \%$ (w/v) agarose NA (Pharmacia, Uppsala, Sweden) gel in 1X TBE buffer containing 0.089 M Tris, $0.089 \mathrm{M}$ boric acid, 0.002 M EDTA, pH 8.0 (USB, Cleveland, OH, USA), and stained with Green gel Safe Nucleic Acid Stain, 10,000 $\mathrm{X}$ in water (Fisher Molecular Biology, Rome, Italy). A Gene Ruler ${ }^{\mathrm{TM}} 100$ bp DNA Ladder Plus (MBI Fermentas, Vilnius, Lithuania) was used as the molecular weight marker. Image acquisition was performed using UVITEC (Eppendorf).

\section{Polymerase chain reaction amplifi-} cation and sequencing of 16S rDNA

The universal 16S rDNA primers, forward primer 8F (5 AGTTGATCCTGGCTCAG3'), and reverse primer 1492R (5 ACCTTGTTACGACTT3') were used for PCR. The PCR amplification was carried out in a reaction mixture containing $\sim 10 \mathrm{ng}$ genomic DNA as template in $25 \mathrm{~mL}$ reaction volumes containing $10 \mathrm{pmol}$ of each primer, $0.2 \mathrm{mM}$ of each dNTP's, $1 \mathrm{U}$ HotMaster Taq (Eppendorf), $2.5 \mathrm{~mL}$ of $10 \mathrm{X}$ HotMaster Taq Buffer (Eppendorf). The reaction conditions were an initial denaturation at $94^{\circ} \mathrm{C}$ for $2 \mathrm{~min}$, followed by 35 cycles at $94^{\circ} \mathrm{C}$ for $30 \mathrm{sec}, 52^{\circ} \mathrm{C}$ for $1 \mathrm{~min}$ and $72^{\circ} \mathrm{C}$ for $1 \mathrm{~min}$. The PCR products were purified using
Montage PCR filter units (Millipore, Billerica, MA, USA). Sequence reactions were carried out using BigDye 3.1 ready reaction mix (Applied Biosystems, Carlsbad, CA, USA) according to the manufacturer's instructions. The sequenced products were separated with a 3130 Genetic Analyzer (Applied Biosystems). Sequences were imported and assembled with the Bionumerics 7.1 software (Applied Maths, Sint-Martens-Latem, Belgium) and submitted to BLAST searches in GenBank (Altschul et al., 1990)

\section{Results}

\section{Microbiological analysis}

Based on the phenotypic cultural characteristic, the morphological examination by the Gram staining, and the biochemical analysis performed on each sample analysed, a total of 10/20 presumptive Arcobacter species were isolated by mCCDA supplemented with CAT (Table 1). The colonies showing white to whitish-grey, small (2-4 mm) diameter, convex and opaque with entire edge, smooth, transparent/translucent were suspected as Arcobacter spp. colonies. Moreover, oxidase and catalase positive and urease negative test revealed presumptive Arcobacter spp. isolates.

\section{Biomolecular analysis}

The isolates were confirmed as Arcobacters by genus-based PCR. Polymerase chain reactions performed on each bacterial pellet samples gave positive results for Arcobacter species in 6/10 (Table 1). Sequence analysis of the amplified 16S rDNA revealed that all Arcobacters isolates have a complete (100\%) homology with $A$. butzleri.

\section{Discussion}

This is the first report of A. butzleri detection in Mytilus galloprovincialis marketed in Apulia region. However, since only 20 samples were analysed, the reported results should be interpreted only as preliminary data and require further sampling and analytical investigations to determine the prevalence of Arcobacter spp. in Italian marketed mussels.

The importance of the genus Arcobacter is due to some species defined as emerging enterophatogens and potential zoonotic agents. The current state-of-the-art on the transmission of Arcobacters to human suggests that the potential routes are represented by food and water contaminated.

Among Arcobacter spp. isolated from food

Table 1. Prevalence of Arcobacter butzleri isolated by cultural method.

\begin{tabular}{|c|c|c|c|}
\hline Samples & $\begin{array}{l}\text { Positive samples } \\
\text { on cultural media }\end{array}$ & $\begin{array}{c}\text { Positive samples } \\
\text { on genus-based PCR (n) }\end{array}$ & $\begin{array}{l}\text { Species detected by } \\
\text { sequencing }\end{array}$ \\
\hline 1 & - & - & \\
\hline 2 & - & - & \\
\hline 3 & + & + & A. butzleri \\
\hline 4 & + & + & A. butzleri \\
\hline 5 & + & + & A. butzleri \\
\hline 6 & - & - & \\
\hline 7 & + & + & A. butzleri \\
\hline 8 & + & - & \\
\hline 9 & - & - & \\
\hline 10 & + & - & \\
\hline 11 & - & - & \\
\hline 12 & - & - & \\
\hline 13 & - & - & \\
\hline 14 & + & + & A. butzleri \\
\hline 15 & - & - & \\
\hline 16 & + & - & \\
\hline 17 & - & - & \\
\hline 18 & + & + & A. butzleri \\
\hline 19 & - & - & \\
\hline 20 & + & - & \\
\hline Total & 10 & 6 & \\
\hline
\end{tabular}

PCR, polymerase chain reaction. 
and water, A. butzleri is the most prevalent species, followed by $A$. cryoaerophilus. Arcobacter spp. have been frequently isolated from products of animal origin (chicken, followed by pork, beef meat, raw milk and dairy products, lamb) (Ho et al., 2006; Fernandez et al., 2001; Maugeri et al., 2000; Giacometti et. al., 2013). Recently Arcobacter spp. were detected in fresh vegetables (Gonzales and Ferrús, 2011), but these foods are generally considered as safe and Arcobacter contamination levels seem to be rather lower than animal food products and waters. Arcobacters have been isolated from environmental waters, including surface waters, ground waters, rivers, lakes, sea water, sewage and from planktons (Fera et al., 2004; Collado et al., 2008; Ghane, 2014). In Italy, Fera et al. (2004) reported the detection of these microrganisms in seawater and plankton samples collected from the Strait of Messina. Collado et al. (2008) confirmed the association of Arcobacter with faecally polluted waters.

Comparing data on the rates of prevalence of the Arcobacters, isolated from different sources, is very difficult. This could be accounted for several reasons, including geographic and temporal variation of sampling. Most of all, the absence of standard diagnostic techniques should be considered as an obstacle, together with inconsistences in the sensitivity and specificity of the various protocols developed. Bivalve shellfish, as a result of their filter-feeding activity, can bioconcentrate pathogens, but few data about Arcobacter spp. occurrence in mussels have been published.

The prevalence of $A$. butzleri in shellfish and the reported incidence rates were $100 \%$ in clams and $41.1 \%$ in mussels (Collado et al., 2009; Maugeri et al., 2000; Fernandez et al., 2001; Romero et al., 2002). New species of the genus Arcobacter have been isolated and identified from shellfish: A. mytili, A. molluscorum, A. ellisii, A. bivalviorum and A. venerupis (Levican et al., 2013).

The results reported here demonstrate the presence of $A$. butzleri in mussels marketed in Apulia region, Italy. These preliminary data require additional investigation in order to assess the epidemiology of this emerging foodborne pathogen, determine the origin of bacterial contamination (i.e. marine production areas), and study the prevalence of Arcobacters in lamellibranch molluscs.

\section{Conclusions}

The occurrence of $A$. butzleri in Italian mussels, marketed in Apulia region, emphasises the need to investigate the impact of Arcobacter spp. on public health, including this source of exposure. Consuming shellfish might be an important health risk when considering that these products are traditionally eaten poorly cooked and/or raw. An effective national food control system is essential to protect the health and safety of consumers, but it must be accompanied by extensive research on emerging pathogens.

\section{References}

Altschul SF, Gish W, Miller W, Myers EW, Lipman DJ, 1990. Basic local alignment search tool. J Mol Biol 215:403-10.

Cardoen S, Van Huffel X, Berkvens D, Quoilin S, Ducoffre G, Saegerman C, Speybroeck N, Imberechts H, Herman L, Ducatelle R, Dierick K, 2009. Evidence-based semiquantitative methodology for prioritization of foodborne zoonoses. Foodborne Pathog Dis 6:1083-96.

Collado L, Figueras MJ, 2011. Taxonomy, epidemiology and clinical relevance of the genus Arcobacter. Clin Microbiol Rev 24:174-92.

Collado L, Guarro J, Figueras MJ, 2008. Presence of Arcobacter spp. in environmental waters correlates with high levels of fecal pollution. Environ Microbiol 10:1635-40.

Collado L, Guarro J, Figueras MJ, 2009. Prevalence of Arcobacter in meat and shellfish. J Food Protect 72:1102-6.

Fera MT, Maugeri TL, Gagliandolo C, Beninati C, Giannone M, La Camera E, Carbone M, 2004. Detection of Arcobacter spp. in the coastal environment of the Mediterranean Sea. Appl Environ Microb 70:1271-6.

Fernandez H, Ott L, Wilson M, Rodriguez R, Proboste B, Saldivia C, Barría P, 2001. Occurrence of Arcobacter sp. in river water, mussles and commercial chicken livers in southern Chile. Int $\mathrm{J}$ Med Microbiol 291:140.

Ghane FGMM, 2014. Isolation of Arcobacter butzleri from Caspian sea's water. Appl Environ Microb 2:61-4.

Giacometti F, Lucchi A, Manfreda G, Florio D, Zanoni RG, Serraino A, 2013. Occurrence and genetic diversity of arcobacter butzleri in an artisanal dairy plant in Italy. Appl Environ Microb 79:6665-9.

González A, Ferrús MA, 2011. Study of Arcobacter spp. contamination in fresh lettuces detected by different cultural and molecular methods. Int J Food Microbiol 145:311-4.

Harmon KM, Wesley IV, 1996. Identification of Arcobacter isolates by PCR. Lett Appl Microbiol 23:241-4.

Hausdorf L, Fröhling A, Schlüter 0, Kloke M, 2011. Analysis of the bacterial community within carrot wash water. Can J Microbiol
57:447-52.

Ho HT, Lipman LJ, Gaastra W, 2006. Arcobacter, what is known and unknown about a potential foodborne zoonotic agent. Vet Microbiol 115:1-3.

ICMFS, 2002. Microorganisms in food. Microbiological testing in food safety management. International Commission on Microbiological Specifications for FoodsKluwer Academic Publ., New York, NY, USA.

ISO, 2003. Microbiology of food and animal feeding stuffs. Preparation of test samples, initial suspension and decimal dilutions for microbiological examination. Part 3: specific rules for the preparation of fish and fishery products. ISO Norm 6887$3: 2003$. International Standardization Organization ed., Geneva, Switzerland.

Jiang ZD, Dupont HL, Brown EL, Nandy K, Ramamurthy T, Sinha A, Ghosh S, Guin S, Gurleen K, Rodrigues S, Chen JJ, McKenzie R, Steffen R, 2010. Microbial etiology of travelers' diarrhea in Mexico, Guatemala, and India: importance of enterotoxigenic bacteroides fragilis and Arcobacter species. J Clin Microbiol 48:1417-9.

Levican A, Collado L, Figueras MJ, 2013. Arcobacter cloacae sp. nov. and Arcobacter suis sp. nov., two new species isolated from food and sewage. Syst Appl Microbiol 36:22-7.

Levican A, Collado L, Yustes C, Aguilar C, Figueras MJ, 2014. Higher water temperature and incubation under aerobic and mictoaerobic conditions increase the recovery and diversity of Arcobacter spp. from shellfish. Appl Environ Microb 80:385-91.

Levican A, Figueras MJ, 2013. Performance of five molecular methods for monitoring Arcobacter spp. BMC Microbiol 13:220.

Maugeri TL, Gugliandolo C, Carbone M, Caccamo D, Fera MT, 2000. Isolation of Arcobacter spp. in the coastal environment of the Mediterranean Sea. Appl Environ Microb 70:1271-6.

Nieva-Echevarria B, Martinez-Malaxetxebarria I, Girbau C, Alonso R, Fernandez-Astorga A, 2013. Prevalence and genetic diversity of Arcobacter in food products in the north of Spain. J Food Protect 76:1447-50.

Ottaviani D, Chierichetti S, Rocchegiani E, Bartolini C, Masini L, Santarelli S, Leoni F, 2013. Bioaccumulation experiments in mussles contaminated with the food-borne pathogen Arcobacter butzleri: preliminary data for risk assessment. Biomed Res Int 2013:153419.

Phillips CA, 2001. Arcobacter spp in food: isolation, identification and control. Trends Food Sci Tech 12:263-75.

Romero J, García-Varela M, Laclette JP, Espejo 
RT, 2002. Bacterial 16S rRNA gene analysis revealed that bacteria related to Arcobacter spp. constitute an abundant and common component of the oyster microbiota (Tiostrea chilensis). Med Microbiol Lett 193:89-94.
Suelam IA, 2012. Isolation and identification of Arcobacter secies recovered from rabbits in Zagazig, Egypt. Int J Microbiol Res 3:8792.

Tabatabaei M, Aski HS, Shayegh H, 2014. Occurrence of six virulence-associated genes in Arcobacter species isolated from various sources in Shiraz, Soutern Iran. Microb Pathogenesis 66:1-4.

Vandamme P, De Ley J, 1991. Proposal for a new family, Campylobacteraceae. Int J Syst Bacteriol 41:451-5. 